\author{
A. Ashyralyev ${ }^{1-3}$, S. Ibrahim ${ }^{1, *}$, E. Hincal ${ }^{1}$ \\ ${ }^{1}$ Near East University, Nicosia, Turkey; \\ ${ }^{2}$ Peoples' Friendship University of Russia (RUDN University), Moscow, Russia; \\ ${ }^{3}$ Institute of Mathematics and Mathematical Modeling, Almaty, Kazakhstan \\ (E-mail: aallaberen@gmail.com, suleiman368@gmail.com, evren.hincal@neu.edu.tr)
}

\title{
On stability of the third order partial delay differential equation with involution and Dirichlet condition
}

\begin{abstract}
In this paper the stability of the initial value problem for the third order partial delay differential equation with involution is investigated. The first order of accuracy absolute stable difference scheme for the solution of the differential problem is presented. Stability estimates for the solution of this difference scheme are proved. Numerical results are provided.
\end{abstract}

Keywords: time delay, third order partial differential equations, stability, difference scheme.

\section{Introduction}

Local and nonlocal boundary value problems for third order partial differential equations have been studied widely in the literature (see, for instance, $[1-8]$ ).

The time delay is one of the most common phenomena occurring in many engineering applications. In control theory the process of sampled-data control is a typical example where time delay happens in the transmission from measurement to controller.

Theory and applications of delay linear and nonlinear third order ordinary differential and difference equations with the delay term were widely investigated (see, for instance, [9-14] and the references given therein).

Our goal in this paper is to investigate the initial value problem for third order partial delay differential and difference equations with convolution. The paper is organized as follows. Section 1 is the introduction. In section 2 the theorem on stability of the initial value problem for the third order partial delay differential equation with convolution is established. In section 3 the first order of accuracy difference scheme for the solution of this problem is studied. Stability estimates for the solution of this difference scheme are proved. In section 4 numerical results are provided. Finally, section 5 is a conclusion.

\section{Stability of differential problem}

In $[0, \infty) \times(-l, l)$ the initial boundary value problem for the third order partial differential equation with time delay and involution

$$
\left\{\begin{array}{l}
\frac{\partial^{3} u(t, x)}{\partial t^{3}}-\left(a(x) u_{t x}(t, x)\right)_{x}+\beta\left(a(-x) u_{t,-x}(t,-x)\right)_{-x} \\
=-b\left(-a(x) u_{x}(t-w, x)\right)_{x}+\beta\left(a(-x) u_{-x}(t,-x)\right)_{-x} \\
+f(t, x), 0<t<\infty,(-l, l) \\
u(t, x)=g(t, x),-w \leq t \leq 0, x \in[-l, l], \\
u(t,-l)=u(t, l)=0,0 \leq t<\infty
\end{array}\right.
$$

is considered. Throughout this paper we will assume that $w>0, \bar{a} \geq a(x)=a(-x) \geq \underline{a}>0, x \in(-l, l)$ and $\underline{a}-\bar{a}|\beta| \geq 0$.

\footnotetext{
${ }^{*}$ Corresponding author.

E-mail: suleiman368@gmail.com
} 
We consider the Hilbert space $L_{2}[-l, l]$ of the all square integrable functions defined on $[-l, l]$, equipped with the norm

$$
\|f\|_{L_{2}[-l, l]}=\left(\int_{-l}^{l}|f(x)|^{2} d x\right)^{\frac{1}{2}} .
$$

Under compatibility conditions problem (1) has a unique solution $u(t, x)$ for the smooth functions $a(x)$, $x \in(-l, l), g(t, x),-w \leq t \leq 0, x \in[-l, l], f(t, x), 0<t<\infty, x \in(-l, l)$, and $b \in R^{1}$.

Let us give theorem on stability of problem (1).

Theorem 1. For the solutions of problem (1) we have following stability estimates

$$
\begin{gathered}
\max _{0 \leq t \leq n w}\left\|v_{t t}(t, \cdot)\right\|_{W_{2}^{1}[-l, l]}, \max _{0 \leq t \leq n w}\left\|v_{t}(t, \cdot)\right\|_{W_{2}^{2}[-l, l]}, \max _{0 \leq t \leq n w}\|v(t, \cdot)\|_{W_{2}^{3}[-l, l]} \\
\leq M_{2}\left[(2+|b| w)^{n} a_{0}+\sum_{j=1}^{n}(2+|b| w)^{n-j} \int_{(j-1) \omega}^{j w}\|f(s, \cdot)\|_{W_{2}^{1}[-l, l]} d s\right], \\
a_{0}=\max \left\{\max _{-w \leq t \leq 0}\left\|g_{t t}(t, \cdot)\right\|_{W_{2}^{1}[-l, l]}, \max _{-w \leq t \leq 0}\|g(t, \cdot)\|_{W_{2}^{3}[-l, l]}\right\},
\end{gathered}
$$

where $M_{2}$ does not depend on $g(t, x)$ and $f(t, x)$. Here, $W_{2}^{1}[-l, l], W_{2}^{2}[-l, l]$ and $W_{2}^{3}[-l, l]$ are Sobolev spaces of all square integrable functions $\psi(x)$ defined on $[-l, l]$ equipped with the norm

$$
\|\psi\|_{W_{2}^{k}[-l, l]}=\left(\int_{-l}^{l} \sum_{j=0}^{k}\left(\psi_{j \text { time }}^{\psi_{x \cdots x}^{\cdots}}(x)\right)^{2} d x\right)^{\frac{1}{2}} .
$$

Proof. This allows us to reduce the problem (1) to the initial value problem

$$
\left\{\begin{array}{c}
\frac{d^{3} v(t)}{d t^{3}}+A \frac{d v(t)}{d t}=b A v(t-w)+f(t), 0<t<\infty, \\
v(t)=g(t),-w \leq t \leq 0
\end{array}\right.
$$

in a Hilbert space $H=L_{2}[-l, l]$ with a self-adjoint positive definite operator $A$ defined by formula

$$
A u(x)=-\left(a(x) u_{x}(x)\right)_{x}+\beta\left(a(-x) u_{-x}(-x)\right)_{-x}
$$

with domain

$$
D(A)=\left\{u(x): u(x), u_{x}(x),\left(a(x) u_{x}\right)_{x} \in L_{2}[-l, l], u( \pm l)=0\right\} .
$$

The proof of Theorem 1 is based on the self-adjointness and positive definiteness of the space operator $A$ defined by formula (3), paper [15] and the following theorem on stability of the solution of the abstract problem (2).

Theorem 2. [16] For the solution of problem (2) the following estimate holds:

$$
\begin{gathered}
\max _{0 \leq t \leq n w}\left\|A^{\frac{1}{2}} \frac{d^{2} v(t)}{d t^{2}}\right\|_{H}, \max _{0 \leq t \leq n w}\left\|A \frac{d v(t)}{d t}\right\|_{H}, \frac{1}{2} \max _{0 \leq t \leq n w}\left\|A^{\frac{3}{2}} v(t)\right\|_{H} \\
\leq(2+|b| w)^{n} a_{0}+\int_{0}^{n w}\left\|A^{\frac{1}{2}} f(s)\right\|_{H} d s, n=1,2, \ldots,
\end{gathered}
$$

where

$$
a_{0}=\max \left\{\max _{-w \leq t \leq 0}\left\|A^{\frac{1}{2}} \frac{d^{2} g(t)}{d t^{2}}\right\|_{H}, \max _{-w \leq t \leq 0}\left\|A \frac{d g(t)}{d t}\right\|_{H}, \max _{-w \leq t \leq 0}\left\|A^{\frac{3}{2}} g(t)\right\|_{H}\right\}
$$

Stability of the difference scheme

Now, we study the stable difference scheme for the approximate solution of the problem (1). The discretization of the problem (1) is carried out in two steps. 
In the first step, the spatial discretization is carried out. We define the grid space

$$
[-l, l]_{h}=\left\{x=x_{n} \mid x_{n}=n h,-M \leq n \leq M, M h=\ell\right\} .
$$

We introduce the Hilbert space $L_{2 h}=L_{2}\left([-l, l]_{h}\right)$ of the grid functions $\varphi^{h}(x)=\left\{\varphi^{n}\right\}_{-M}^{M}$ defined on $[-l, l]_{h}$, equipped with the norm

$$
\left\|\varphi^{h}\right\|_{L_{2 h}}=\left(\sum_{x \in[-l, l]_{h}}\left|\varphi^{h}(x)\right|^{2} h\right)^{1 / 2} .
$$

To the differential operator $A$ defined by the formula (3), we assign the difference operator $A_{h}^{x}$ by the formula

$$
A_{h}^{x} \varphi^{h}(x)=\left\{-\left(a(x) \varphi_{\bar{x}}^{n}\right)_{x}-\beta\left(a(-x) \varphi_{\bar{x}}^{-n}\right)_{x}\right\}_{-M+1}^{M-1},
$$

acting in the space of grid functions $\varphi^{h}(x)=\left\{\varphi^{n}\right\}_{-M}^{M}$ and satisfying the conditions $\varphi^{-M}=\varphi^{M}=0$. Here

$$
\varphi_{\bar{x}}^{n}=\frac{\varphi^{n}-\varphi^{n-1}}{h},-M+1 \leq n \leq M, \quad \varphi_{x}^{n}=\frac{\varphi^{n+1}-\varphi^{n}}{h},-M \leq n \leq M-1 .
$$

It is well-known that $A_{h}^{x}$, defined by (4), is a self-adjoint positive definite operator in $L_{2 h}$. With the help of $A_{h}^{x}$ the first discretization step results in the following problem

$$
\left\{\begin{array}{l}
\frac{\partial^{3} u^{h}(t, x)}{\partial t^{3}}+A_{h}^{x} u^{h}(t, x)=-b A_{h}^{x} u^{h}(t-w, x) \\
+f^{h}(t, x), x \in[-l, l]_{h}, 0<t<\infty \\
u^{h}(t, x)=g^{h}(t, x),-w \leq t \leq 0, x \in[-l, l]_{h},-w<t<0 .
\end{array}\right.
$$

In the second step we replace the problem (5) with the following first order of accuracy difference scheme

$$
\left\{\begin{array}{l}
\frac{u_{k+2}^{h}(x)-3 u_{k+1}^{h}(x)+3 u_{k}^{h}(x)-u_{k-1}^{h}(x)}{\tau^{3}}+A_{h}^{x} \frac{u_{k+2}^{h}(x)-u_{k+1}^{h}(x)}{\tau} \\
=b A_{h}^{x} u_{k-N}^{h}(x)+f_{k}^{h}(x), f_{k}^{h}(x)=f^{h}\left(t_{k}, x\right), k \geq 1, \quad x \in[-l, l]_{h}, \\
u_{k}^{h}(x)=g^{h}\left(t_{k}, x\right),-N \leq k \leq 0, \\
\left(I_{h}+\tau^{2} A_{h}^{x}\right) \frac{u_{1}^{h}(x)-u_{0}^{h}(x)}{\tau}=g_{t}^{h}(0, x), \\
\left(I_{h}+\tau^{2} A_{h}^{x}\right) \frac{u_{2}^{h}(x)-2 u_{1}^{h}(x)+u_{0}^{h}(x)}{\tau^{2}}=g_{t t}^{h}(0, x), x \in[-l, l]_{h}, \\
\left(I_{h}+\tau^{2} A_{h}^{x}\right) \frac{u_{m N+1}^{h}(x)-u_{m N}^{h}(x)}{\tau}=\frac{u_{m N}^{h}(x)-u_{m N-1}^{h}(x)}{\tau}, x \in[-l, l]_{h}, \\
\left(I_{h}+\tau^{2} A_{h}^{x}\right) \frac{u_{m N+2}^{h}(x)-2 u_{m N+1}^{h}(x)+u_{m N}^{h}(x)}{\tau^{2}} \\
=\frac{u_{m N}^{h}(x)-2 u_{m N-1}^{h}(x)+u_{m N-2}^{h}(x)}{\tau^{2}}, x \in[-l, l]_{h}, m=1,2, \ldots,
\end{array}\right.
$$

where $\tau=1 / N$ and $t_{k}=k \tau,-N \leq k<\infty$.

Theorem 3. Let $\tau$ and $h$ be sufficiently small numbers. For the solution of difference scheme (6) the following estimates

$$
\begin{gathered}
\max _{0 \leq k \leq(m+1) N-2}\left\|\frac{u_{k+2}^{h}-2 u_{k+1}^{h}+u_{k}^{h}}{\tau^{2}}\right\|_{W_{2 h}^{1}}, \max _{1 \leq k \leq(m+1) N}\left\|\frac{u_{k}^{h}-u_{k-1}^{h}}{\tau}\right\|_{W_{2 h}^{2}}, \\
\max _{0 \leq k \leq(m+1) N}\left\|u_{k}^{h}\right\|_{W_{2 h}^{3}} \leq C_{1}\left[(2+\tau|b|(N-2))^{m} b_{0}^{h}\right. \\
\left.+\sum_{j=1}^{m}(2+\tau|b|(N-2))^{m-j} \tau \sum_{s=(j-1) N+1}^{j N}\left\|f\left(t_{s}\right)\right\|_{W_{2 h}^{1}}\right], m=0,1, \ldots,
\end{gathered}
$$




$$
b_{0}^{h}=\max \left\{\max _{-N \leq k \leq 0}\left\|g_{t t}^{h}\left(t_{k}\right)\right\|_{W_{2 h}^{1}}, \quad \max _{-N \leq k \leq 0}\left\|g_{t}^{h}\left(t_{k}\right)\right\|_{W_{2 h}^{2}}, \quad \max _{-N \leq k \leq 0}\left\|g^{h}\left(t_{k}\right)\right\|_{W_{2 h}^{3}}\right\}
$$

hold, where $C_{1}$ does not depend on $\tau, h, g^{h}\left(t_{k}\right)$, and $f_{k}^{h}(x)$. Here, $W_{2 h}^{1}, W_{2 h}^{2}$ and $W_{2 h}^{3}$ are spaces of all mesh functions $\psi^{h}(x)$ defined on $[-l, l]_{h}$ equipped with the norm

$$
\left\|\psi^{h}\right\|_{W_{2 h}^{k}}=\left(\sum_{x \in[-l, l]} \sum_{j=0}^{k}(\underbrace{\psi^{h} \cdots x}_{j \text { time }}(x))^{2} h^{k}\right)^{\frac{1}{2}} .
$$

Proof. Difference scheme (6) can be written in abstract form

$$
\left\{\begin{array}{l}
\frac{u_{k+2}^{h}-3 u_{k+1}^{h}+3 u_{k}^{h}-u_{k-1}^{h}}{\tau^{3}}+A_{h} \frac{u_{k+2}^{h}-u_{k+1}^{h}}{\tau}=b A_{h} u_{k-N}^{h}+f_{k}^{h}, k \geq 1, \\
u_{k}^{h}=g_{k}^{h},-N \leq k \leq 0, \\
\left(I_{h}+\tau^{2} A_{h}\right) \frac{u_{1}^{h}-u_{0}^{h}}{\tau}=g_{t}^{h}(0),\left(I_{h}+\tau^{2} A_{h}\right) \frac{u_{2}^{h}-2 u_{1}^{h}+u_{0}^{h}}{\tau^{2}}=g_{t t}^{h}(0), \\
\left(I_{h}+\tau^{2} A_{h}\right) \frac{u_{m N+2}^{h}-2 u_{m N+1}^{h}+u_{m N}^{h}}{\tau^{2}}=\frac{u_{m N}^{h}-2 u_{m N-1}^{h}+u_{m N-2}^{h}}{\tau^{2}}, \\
\left(I_{h}+\tau^{2} A_{h}\right) \frac{u_{m N+1}^{h}-u_{m N}^{h}}{\tau}=\frac{u_{m N}^{h}-u_{m N-1}^{h}}{\tau}, m=1,2, \ldots
\end{array}\right.
$$

in a Hilbert space $L_{2 h}$ with self-adjoint positive definite operator $A_{h}=A_{h}^{x}$, which is defined by formula (4). Here, $g_{k}^{h}=g_{k}^{h}(x), f_{k}^{h}=f_{k}^{h}(x)$ and $u_{k}^{h}=u_{k}^{h}(x)$ are known and unknown abstract mesh functions defined on $[-l, l]_{h}$ with the values in $H=L_{2 h}$. Therefore, the proof of Theorem 2 is based on the self-adjointness and positive definiteness of the space operator $A_{h}(4)$ [17] and the following theorem on stability of the solution of the difference scheme (7).

Theorem 4. [18] For the solution of difference scheme (7) the following estimate holds:

$$
\begin{gathered}
\frac{1}{2} \max _{0 \leq k \leq(m+1) N-2}\left\|A_{h}^{\frac{1}{2}} \frac{u_{k+2}^{h}-2 u_{k+1}^{h}+u_{k}^{h}}{\tau^{2}}\right\|_{H}, \max _{1 \leq k \leq(m+1) N}\left\|A_{h} \frac{u_{k}^{h}-u_{k-1}^{h}}{\tau}\right\|_{H}, \\
\max _{0 \leq k \leq(m+1) N}\left\|A_{h}^{\frac{3}{2}} u_{k}^{h}\right\|_{H} \leq C_{1}\left[(2+\tau|b|(N-2))^{m} b_{0}^{h}\right. \\
\left.+\sum_{j=1}^{m}(2+\tau|b|(N-2))^{m-j} \tau \sum_{s=(j-1) N+1}^{j N}\left\|A_{H}^{\frac{1}{2}} f\left(t_{s}\right)\right\|_{H}\right], m=0,1, \ldots
\end{gathered}
$$

where

$$
b_{0}=\max \left\{\max _{-N \leq k \leq 0}\left\|A_{h}^{\frac{1}{2}} g^{\prime \prime}\left(t_{k}\right)\right\|_{H}, \quad \max _{-N \leq k \leq 0}\left\|A_{h} g_{t}^{h}\left(t_{k}\right)\right\|_{H}, \quad \max _{-N \leq k \leq 0}\left\|A_{h}^{\frac{3}{2}} g^{h}\left(t_{k}\right)\right\|_{H}\right\} .
$$

\section{Numerical results}

The numerical methods for obtaining the approximate solutions of partial differential equations play an important role in applied mathematics when the analytical methods do not work properly. In this section we will use the first order of accuracy difference scheme to approximate the solution of a simple test problem

$$
\left\{\begin{array}{l}
\frac{\partial^{3} u(t, x)}{\partial t^{3}}-\frac{\partial^{3} u(t, x)}{\partial t \partial x^{2}}+16 \frac{\partial u(t, x)}{\partial t}-\frac{1}{8} \frac{\partial^{3} u(t,-x)}{\partial t \partial x^{2}}+2 \frac{\partial u(t,-x)}{\partial t} \\
=-0.1\left(-\frac{\partial^{2} u(t-1, x)}{\partial x^{2}}+16 u(t-1, x)\right)-43 e^{-2 t} \sin 2 x+2 e^{-2(t-1)} \sin 2 x \\
0<t<\infty,-\pi<x<\pi \\
u(t, x)=e^{-2 t} \sin 2 x,-1 \leq t \leq 0,-\pi \leq x \leq \pi \\
u(t,-\pi)=u(t, \pi)=0, \quad 0 \leq t<\infty
\end{array}\right.
$$


The exact solution of problem (8) is $u(t, x)=e^{-2 t} \sin 2 x,-\pi \leq x \leq \pi,-1 \leq t<\infty$. For the approximate solutions of the problem (8), using the set of grid points

$$
[-1, \infty)_{\tau} \times[-\pi, \pi]_{h}=\left\{\left(t_{k}, x_{n}\right): t_{k}=k \tau,-N \leq k, N \tau=1, x_{n}=n h,-M \leq n \leq M, M h=\pi\right\}
$$

we get the first order of accuracy in $t$ difference scheme

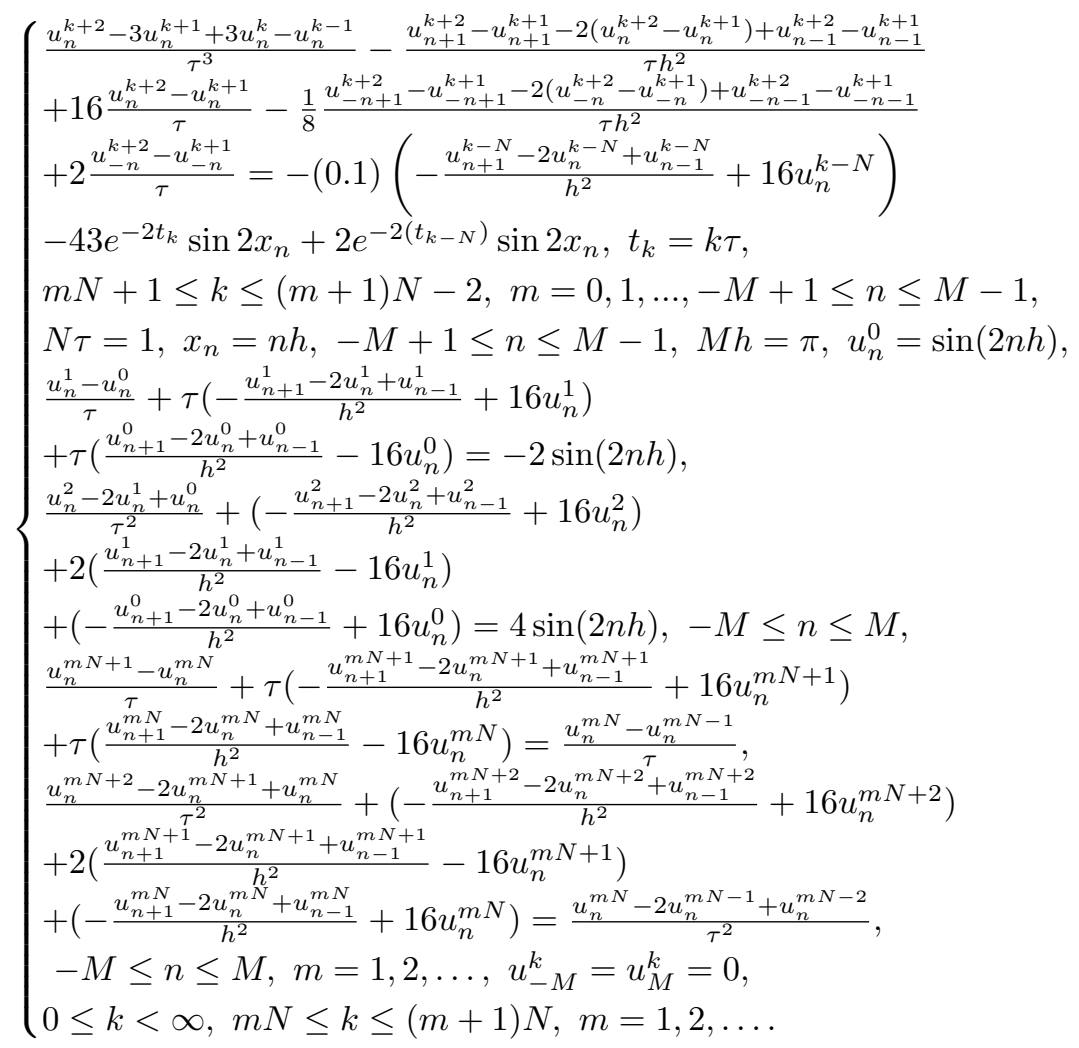

We can write (9) in the matrix form

$$
\left\{\begin{array}{l}
B U^{k+2}+C U^{k+1}+D U^{k}+E U^{k-1}=\varphi\left(U^{k-N}\right), k=1,2,3, \ldots \\
0 \\
U^{0}=\left[\begin{array}{c}
\sin (2(-M+1) h) \\
\vdots \\
\sin (2(M-1) h) \\
0
\end{array}\right] \\
U^{1}=\left(\begin{array}{c}
1-2 \tau) U^{0} \\
U^{2}=2 U^{1}-\left(1-4 \tau^{2}\right) U^{0} \\
U^{m N+1}=F^{-1} H U^{m N}-F^{-1} U^{m N-1} \\
U^{m N+2}=2 U^{m N+1}+F^{-1} P U^{m N}-2 F^{-1} U^{m N-1}+F^{-1} U^{m N-2} \\
m=1,2, \ldots,
\end{array}\right.
\end{array}\right.
$$

where $B, C, D, E, F, H$ and $P$ are $(2 M+1) \times(2 M+1)$ matrices, $\varphi\left(U^{k-N}\right), U^{0}, U^{1}$ and $U^{r}, r=k, k \pm 1, k+2$ are $(2 M+1) \times 1$ column vectors defined by 


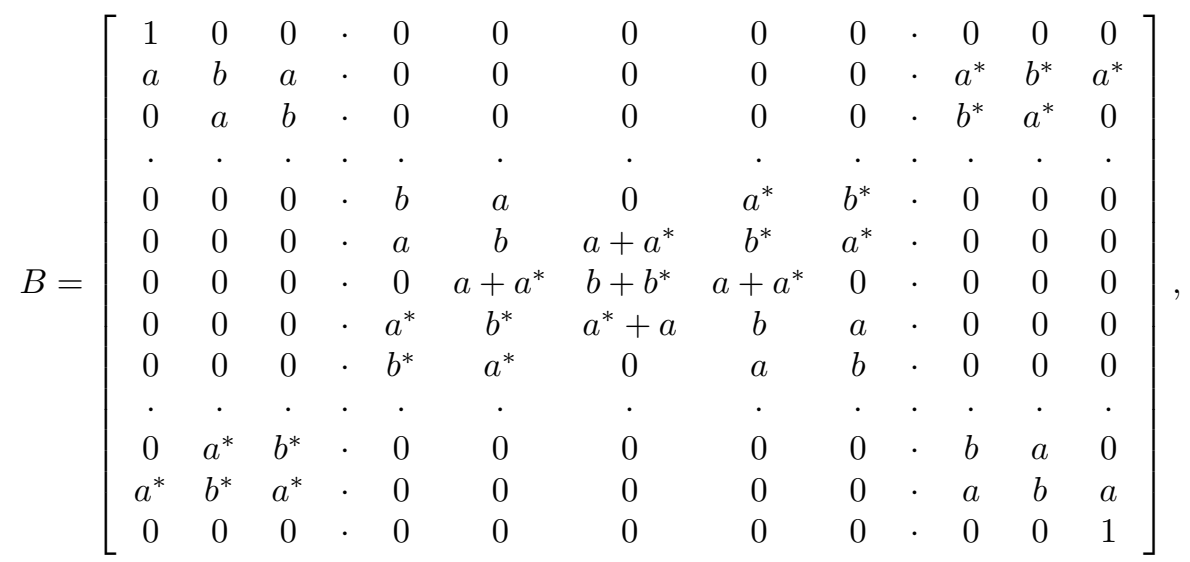

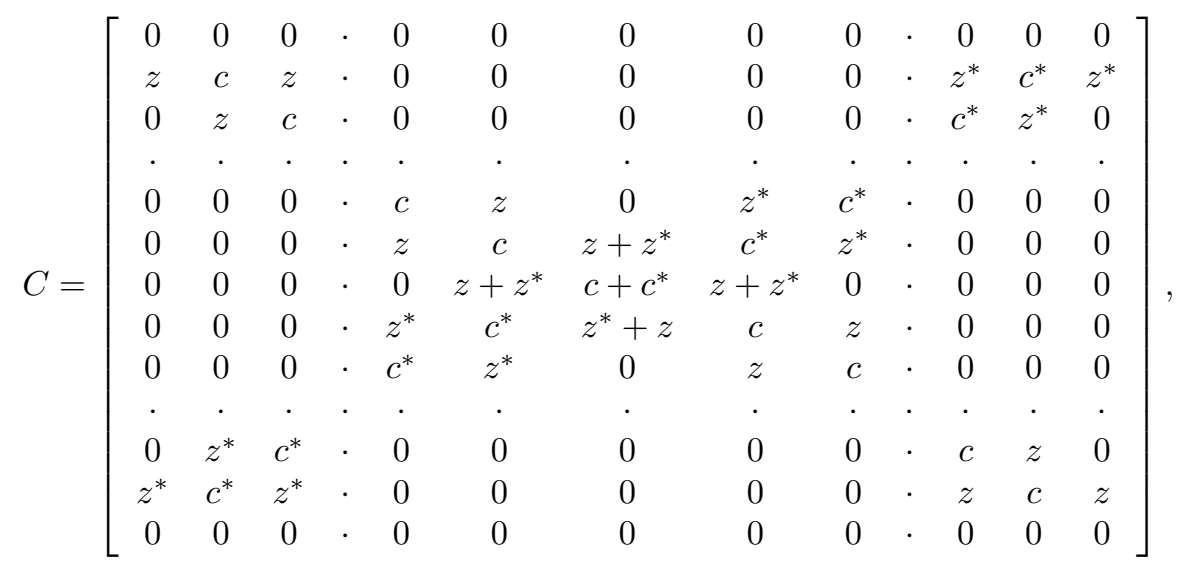

$$
\begin{aligned}
& D=\left[\begin{array}{lllllll}
0 & 0 & 0 & . & 0 & 0 & 0 \\
0 & d & 0 & . & 0 & 0 & 0 \\
0 & 0 & d & . & 0 & 0 & 0 \\
. & . & . & . & . & . & . \\
0 & 0 & 0 & . & d & 0 & 0 \\
0 & 0 & 0 & . & 0 & d & 0 \\
0 & 0 & 0 & . & 0 & 0 & 0
\end{array}\right], E=\left[\begin{array}{lllllll}
0 & 0 & 0 & . & 0 & 0 & 0 \\
0 & e & 0 & . & 0 & 0 & 0 \\
0 & 0 & e & . & 0 & 0 & 0 \\
. & . & . & . & . & . & . \\
0 & 0 & 0 & . & e & 0 & 0 \\
0 & 0 & 0 & . & 0 & e & 0 \\
0 & 0 & 0 & . & 0 & 0 & 0
\end{array}\right]
\end{aligned}
$$

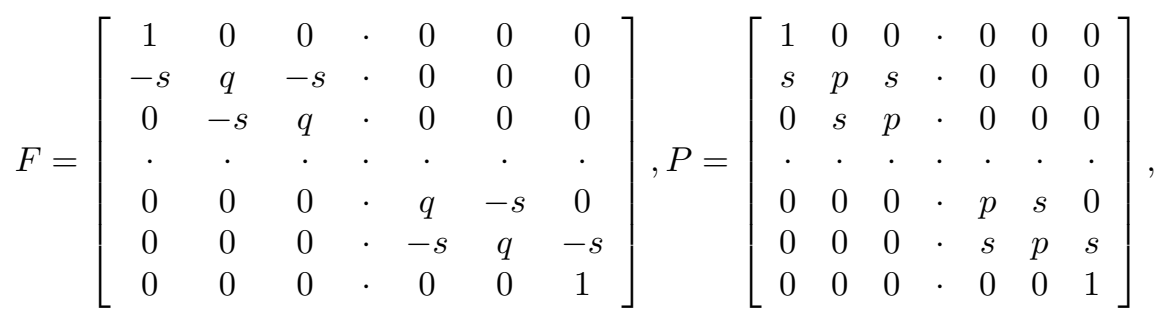

$$
\begin{aligned}
& H=\left[\begin{array}{ccccccc}
1 & 0 & 0 & \cdot & 0 & 0 & 0 \\
-s & t^{*} & -s & \cdot & 0 & 0 & 0 \\
0 & -s & t^{*} & \cdot & 0 & 0 & 0 \\
. & \cdot & . & . & . & . & . \\
0 & 0 & 0 & . & t^{*} & -s & 0 \\
0 & 0 & 0 & \cdot & -s & t^{*} & -s \\
0 & 0 & 0 & . & 0 & 0 & 1
\end{array}\right], \varphi\left(U^{k-N}\right)=\left[\begin{array}{c}
0 \\
\varphi_{-M+1}^{k} \\
\vdots \\
\varphi_{M-1}^{k} \\
0
\end{array}\right], U^{r}=\left[\begin{array}{c}
U_{0}^{r} \\
U_{-M+1}^{r} \\
\vdots \\
U_{M-1}^{r} \\
U_{M}^{r}
\end{array}\right] \text {, }
\end{aligned}
$$


$r=k, k \pm 1, k+2$, where

$$
\begin{aligned}
& \varphi_{n}^{k}=-(0.1)\left(-\frac{u_{n+1}^{k-N}-2 u_{n}^{k-N}+u_{n-1}^{k-N}}{h^{2}}+16 u_{n}^{k-N}\right) \\
& \quad-43 e^{-2 t_{k}} \sin 2 x_{n}+2 e^{-2\left(t_{k-N}\right)} \sin 2 x_{n}, \\
& t_{k}=k \tau, m N+1 \leq k \leq(m+1) N-2, m=0,1, \ldots,-M+1 \leq n \leq M-1 .
\end{aligned}
$$

Here, we denote $a=-\frac{1}{\tau h^{2}}, a^{*}=-\frac{1}{8 \tau h^{2}}, b=\frac{1}{\tau^{3}}+\frac{2}{\tau h^{2}}+\frac{16}{\tau}$,

$b^{*}=\frac{2}{8 \tau h^{2}}+\frac{2}{\tau}, c^{*}=-b^{*}, z^{*}=-a^{*}, z=-a, c=-\frac{3}{\tau^{3}}-\frac{2}{\tau h^{2}}-\frac{16}{\tau}, d=\frac{3}{\tau^{3}}, e=-\frac{1}{\tau^{3}}$,

$t^{*}=2+\frac{2 \tau^{2}}{h^{2}}+16 \tau^{2}, p=-\frac{2 \tau^{2}}{h^{2}}-16 \tau^{2}, q=1+\frac{2 \tau^{2}}{h^{2}}+16 \tau^{2}, \quad s=\frac{\tau^{2}}{h^{2}}$.

The numerical solutions are recorded for different values of $N$ and $M$, and $u_{n}^{k}$ represents the numerical solution of this difference scheme at $u\left(t_{k}, x_{n}\right)$. Table 1 is constructed for $N=M=40,80,160$ in $t \in[0,1]$, $t \in[1,2], t \in[2,3]$ respectively and the errors are computed by

$$
m E_{M}^{N}=\max _{m N+1 \leq k \leq(m+1) N,-M \leq n \leq M}\left|u\left(t_{k}, x_{n}\right)-u_{n}^{k}\right| .
$$

Table 1

\section{Errors of Difference Scheme (9)}

\begin{tabular}{|c|l|l|l|}
\hline$(\mathbf{N}, \mathbf{M})$ & $\mathbf{N}=\mathbf{M}=\mathbf{4 0}$ & $\mathbf{N}=\mathbf{M}=\mathbf{8 0}$ & $\mathbf{N}=\mathbf{M}=\mathbf{1 6 0}$ \\
\hline$t \in[0,1]$ & 0.0784 & 0.0397 & 0.0198 \\
\hline$t \in[1,2]$ & 0.0852 & 0.0423 & 0.0210 \\
\hline$t \in[2,3]$ & 0.0679 & 0.0312 & 0.0139 \\
\hline
\end{tabular}

If $N$ and $M$ are doubled, the values of the errors are decreased by a factor of approximately $1 / 2$ for the first order difference scheme (9). The errors presented in this table indicates the accuracy of difference scheme.

\section{Conclusion}

In this paper the stability of the initial boundary value problem for the third order partial delay differential equation with involution is investigated. The first order of accuracy difference scheme for the solution of this problem is presented. Stability estimates for the solution of this difference scheme are proved. Numerical results are provided. Some statements of the present paper were published, without proof, in [16, 19].

\section{Acknowledgements}

We would like to thank the following institutions for their support. The publication has been prepared with the support of the "RUDN University Program 5-100". This research has been funded by the Science Committee of the Ministry of Education and Science of the Republic of Kazakhstan (Grant No. AP08855352).

\section{References}

1 Amirov S. Mixed boundary value problem for a class of strongly nonlinear sobolev-type equations of higher order / S. Amirov, A.I. Kozhanov // Doklady Mathematics. - 2013. - 88. - No. 1. - P. 446-448.

2 Niu J. Numerical algorithm for the third-order partial differential equation with three-point boundary value problem / J. Niu, P. Li // Abstract and Applied Analysis. - 2014. - 2014(630671).

3 Apakov Y. On the solution of a boundary-value problem for a third-order equation with multiple characteristics / Y. Apakov // Ukrainian Mathematical Journal. - 2012. - 64. - P. 1-12.

4 Apakov Y. Boundary-value problem for a generate high-odd order equation / Y. Apakov, B. Irgashev // Ukrainian Mathematical Journal. - 2015. - 66. - P. 1475-1490.

5 Apakov Y. On a boundary value problem to third order pde with multiple characteristics / Y. Apakov, S. Rutkauskas // Nonlinear Analysis: Modelling and Control. - 2011. - 16. - P. 255-269.

6 Belakroum K. A note on the nonlocal boundary value problem for a third order partial differential equation / K. Belakroum, A. Ashyralyev, A. Guezane-Lakoud // Filomat. - 2018. - 32. - No. 3. - P. 801-808. 
7 Kudu M. Method of lines for third order partial differential equations / M. Kudu, I. Amirali // Journal of Applied Mathematics. - 2014. - 2. - No. 2. - P. 33-36.

8 Latrous C. A three-point boundary value problem with an integral condition for a third-order partial differential equation / C. Latrous, A. Memou // Abstract and Applied Analysis. - 2005. - 2005. P. 33-43.

9 Cahlon B. Stability criteria for certain third-order delay differential equations / B. Cahlon, D. Schmidt // Journal of Computional and Applied Mathematics. - 2006. - 188. - P. 319-335.

10 Baculíková B. Oscillation of third order trinomial delay differential equations / B. Baculíková, J. Dzurina, Y.V. Rogovchenko // Applied Mathematics and Computation. - 2012. - 218. - P. 7023-7033.

11 Afuwape A. U. Stability and boundedness of solutions of a kind of third-order delay differential equations / A.U. Afuwape, M.O. Omeike // Computational and Applied Mathematics. - 2010. — 29. - P. 329-342.

12 Grace S.R. Oscillation criteria for a third order nonlinear delay differential equations with time delay / S.R. Grace // Opuscula Mathematica. - 2015. - 35. - P. 485-497.

13 Xiang H. Oscilation of the third-order nonlinear neutral differential equations with distributed time delay / H. Xiang // Italian Journal of Pure and Applied Mathematics. - 2016. - 36. - P. 769-782.

14 Pikina G.A. Predictive time optimal algorithm for a third-order dynamical system with delay / G.A. Pikina // Journal of Physics: Conference Series. - 2017. - 891. - P. 012278.

15 Ashyralyev A. Well-posedness of an elliptic equation with involution / A. Ashyralyev, A.M. Sarsenbi // Electronic Journal of Differential Equations. - 2015. - 284. - P. 1-8.

16 Ashyralyev A. Stability of the third order partial differential equations with time delay / A. Ashyralyev, E. Hincal, S. Ibrahim // AIP Conference Proceedings. - 2018. - 1997(020086).

17 Ashyralyev On the absolute stable difference scheme for the third order partial differential equation with time delay / A. Ashyralyev, E. Hincal, S. Ibrahim //Symmetry. - 12. - No.6. - Article Number: 1033. DOI: $10.3390 /$ sym12061033.

18 Ashyralyev A. A Note on the parabolic identification problem with involution and Dirichlet condition / A. Ashyralyev, A.S. Erdogan, A.M. Sarsenbi // Bulletin of the Karaganda University-Mathematics. 2020. - 99. - No.3. - P. 130-139.

19 Ashyralyev A. A numerical algorithm for the third order partial differential equation with time delay / A. Ashyralyev, E. Hincal, S. Ibrahim // AIP Conference Proceedings. - 2019. - 2183(070014).

\author{
А. Ашыралыев ${ }^{1-3}$, С. Ибрахим ${ }^{1}$, Е. Хинжал ${ }^{1}$ \\ ${ }^{1}$ Таяу Шызыс университеті, Никосия, Түркия; \\ ${ }^{2}$ Ресей халықтар достыъы университеті, Мәскеу, Ресей; \\ ${ }^{3}$ Математика және математикалық, модельдеу институты, Алматы, Қазақстан
}

\title{
Инволюция және Дирихле шарты бар үшінші ретті дербес туындылы кешігуі бар дифференциалдық теңдеудің тұрақтылығы туралы
}

\begin{abstract}
Мақалада үшінші ретті дербес туындылы кешігуі бар дифференциалдық теңдеудің бастапқы есебінің тұрақтылығы зерттелген. Дифференциалдық есепті шешу үшін бірінші ретті дәлдікті абсолютті тұрақты айырымдық схемасы ұсынылған. Осы айырымдық схема үшін шешімнің тұрақтылығының бағалаулары дәлелденді. Сандық нәтижелер келтірілген.
\end{abstract}

Kiлm сөздер: кешігу, үшінші ретті дербес туындылы теңдеулер, тұрақтылық, айырымдық схема. 


\author{
А. Ашыралыев ${ }^{1-3}$, С. Ибрахим ${ }^{1}$, Е. Хинжал ${ }^{1}$ \\ ${ }^{1}$ Ближневосточный университет, Никосия, Турция; \\ ${ }^{2}$ Российский университет дружбъ народов, Москва, Россия; \\ ${ }^{3}$ Институт математики и математического моделирования, Алматы, Казахстан
}

\title{
Об устойчивости запаздывающего дифференциального уравнения в частных производных третьего порядка с инволюцией и условием Дирихле
}

\begin{abstract}
В статье исследована устойчивость начальной задачи для запаздывающего дифференциального уравнения в частных производных третьего порядка. Представлена абсолютно устойчивая разностная схема первого порядка точности для решения дифференциальной задачи. Доказаны оценки устойчивости решения этой разностной схемы. Приведены численные результаты.
\end{abstract}

Ключевые слова: запаздывание, уравнения в частных производных третьего порядка, устойчивость, разностная схема.

\section{References}

1 Amirov, S., \& Kozhanov, A.I. (2013). Mixed boundary value problem for a class of strongly nonlinear sobolev-type equations of higher order. Doklady Mathematics, 88(1), 446-448.

2 Niu, J., \& Li, P. (2014). Numerical algorithm for the third-order partial differential equation with threepoint boundary value problem. Abstract and Applied Analysis, 2014, 630671.

3 Apakov, Y. (2012). On the solution of a boundary-value problem for a third-order equation with multiple characteristics. Ukrainian Mathematical Journal, 64, 1-12.

4 Apakov, Y., \& Irgashev, B. (2015). Boundary-value problem for a generate high-odd order equation. Ukrainian Mathematical Journal, 66, 1475-1490.

5 Apakov, Y., \& Rutkauskas, S. (2011). On a boundary value problem to third order pde with multiple characteristics. Nonlinear Analysis: Modelling and Control, 16, 255-269.

6 Belakroum, K., Ashyralyev, A., \& Guezane-Lakoud, A. (2018). A note on the nonlocal boundary value problem for a third order partial differential equation. Filomat, 32(3), 801-808.

$7 \mathrm{Kudu}$, M., \& Amirali, I. (2014). Method of lines for third order partial differential equations. Journal of Applied Mathematics, 2(2), 33-36.

8 Latrous, C., \& Memou, A. (2005). A three-point boundary value problem with an integral condition for a third-order partial differential equation. Abstract and Applied Analysis, 2005, 33-43.

9 Cahlon, B., \& Schmidt, D. (2006). Stability criteria for certain third-order delay differential equations. Journal of Computional and Applied Mathematics, 188, 319-335.

10 Baculíková, B., Dzurina, J., \& Rogovchenko, Y.V. (2012). Oscillation of third order trinomial delay differential equations. Applied Mathematics and Computation, 218, 7023-7033.

11 Afuwape, A. U., \& Omeike, M.O. (2010). Stability and boundedness of solutions of a kind of third-order delay differential equations. Computational and Applied Mathematics, 29, 329-342.

12 Grace, S.R.(2015). Oscillation criteria for a third order nonlinear delay differential equations with time delay. Opuscula Mathematica, 35, 485-497.

13 Xiang, H. (2016). Oscilation of the third-order nonlinear neutral differential equations with distributed time delay. Italian Journal of Pure and Applied Mathematics, 36, 769-782.

14 Pikina, G.A. (2017). Predictive time optimal algorithm for a third-order dynamical system with delay. Journal of Physics: Conference Series, 891, 012278.

15 Ashyralyev, A., \& Sarsenbi, A.M. (2015). Well-posedness of an elliptic equation with involution. Electronic Journal of Differential Equations, 284, 1-8.

16 Ashyralyev, A., Hinca,l E., \& Ibrahim, S. (2018). Stability of the third order partial differential equations with time delay. AIP Conference Proceedings, 199\%, 020086. 
17 Ashyralyev, A., Hincal, E., \& Ibrahim, S. (2020). On the absolute stable difference scheme for the third order partial differential equation with time delay. Symmetry, 12(6), ID 1033. DOI: 10.3390/sym12061033.

18 Ashyralyev, A., Erdogan, A.S., \& Sarsenbi, A. M. (2020). A note on the parabolic identification problem with involution and Dirichlet condition. Bulletin of the Karaganda University Mathematics, 99(3), 130139.

19 Ashyralyev, A., Hincal, E., \& Ibrahim, S. (2019). A numerical algorithm for the third order partial differential equation with time delay. AIP Conference Proceedings, 2183, 070014. 